
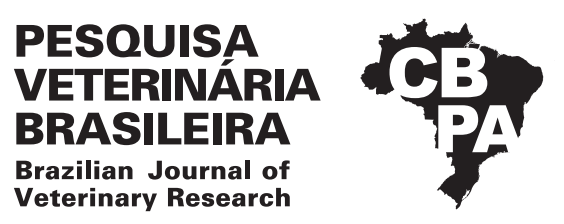

Pesq. Vet. Bras. 39(7):538-548, July 2019 DOI: $10.1590 / 1678-5150-P V B-5848$

Original Article

ISSN 0100-736X (Print)

ISSN 1678-5150 (Online)

\title{
Morphology and biometry of the reproductive organs of adult males of Trachemys scripta elegans reared in São Paulo state, Brazil ${ }^{1}$
}

\author{
Adriana Gradela ${ }^{* *}$ (D), Isabelle Caroline Pires ${ }^{2}$, Marcelo D. Faria², \\ Maria Helena T. Matos ${ }^{2}$, Mateus M. Costa ${ }^{2}$, Rita Kayla C. Souza ${ }^{2}$, \\ Liliane Milanelo ${ }^{3}$ and Vanessa S. Franzo ${ }^{4}$
}

\begin{abstract}
Gradela A., Pires I.C., Faria M.D., Matos M.H.T., Costa M.M., Souza R.K.C., Milanelo L. \& Franzo V.S. 2019. Morphology and biometry of the reproductive organs of adult males of Trachemys scripta elegans reared in São Paulo state, Brazil. Pesquisa Veterinária Brasileira 39(7):538-548. Laboratório de Anatomia dos Animais Domésticos e Silvestres, Colegiado de Medicina Veterinária, Universidade Federal do Vale do São Francisco, Rodovia 407 Km 12, Lote 543, Projeto Nilo Coelho C1, Petrolina, PE 56300-000, Brazil. E-mail: agradela@hotmail.com

Trachemys scripta elegans is an American underwater chelonian illegally marketed in Brazilian pet shops. When abandoned in nature, it compromises native species, threatening local biodiversity. However, little is known about the body development and structure of its reproductive tract. The objective of the present study was to investigate the morphology and biometry of testis, epididymis and penis, as well as the biometry of the body and secondary sexual characters in this species. Twenty-seven adult males were used aiming to contribute to preservation actions in captivity, population control, and scientific research, as well as to interspecific comparisons. Sex identification by the third claw length was effective, and the specimens presented harmonious and positive body development between mass, carapace, plastron, and height, with unimodal tendency and higher frequency of maximum carapace length at $15 \mathrm{~cm}$. The testes and epididymides presented biometric similarity between the antimeres and anatomical and histological structure similar to that of other species of chelonians and mammals, except for the type of epithelium. The findings suggest that there is conserved morphology between slider turtles and homology in relation to mammals. Histological similarity to the reproductive organs of other amniotes, including humans, may give rise to scientific and comparative studies, essential for the establishment of conservation strategies in reptiles.
\end{abstract}

INDEX TERMS: Morphology, biometry, reproductive organs, Trachemys scripta elegans, Brazil, testis, penis, epididymis, turtle, reptiles.

RESUMO.- [Morfologia e biometria dos órgãos reprodutivos de machos adultos de Trachemys scripta elegans criados em São Paulo, Brasil.] Trachemys scripta elegans é um quelônio subaquático americano ilegalmente comercializado

\footnotetext{
${ }^{1}$ Received on September 25, 2018.

Accepted for publication on January 28, 2019.

${ }^{2}$ Universidade Federal do Vale do São Francisco (Univasf), Rodovia $407 \mathrm{Km} \mathrm{12,} \mathrm{Lote} \mathrm{543,} \mathrm{Projeto} \mathrm{Nilo} \mathrm{Coelho} \mathrm{C1,} \mathrm{Petrolina,} \mathrm{PE} \mathrm{56300-000,}$ Brazil. *Corresponding author: agradela@hotmail.com

${ }^{3}$ Centro de Recuperação de Animais Selvagens (CRAS), Parque Ecológico do Tietê (PET), Departamento de Águas e Energia Elétrica (DAEE), Rua Guira Acangatara 70, Engenheiro Goulart, Guarulhos, SP 03719-000, Brazil.

${ }^{4}$ Universidade Federal do Mato Grosso (UFMT), Av. Fernando Correa da Costa 2367, Boa Esperança, Cuiabá, MT 78060-900, Brazil.
}

em pet shops brasileiros. Ao ser abandonado na natureza, compromete as espécies nativas, ameaçando à biodiversidade local. No entanto, pouco se conhece sobre o desenvolvimento corporal e a estrutura do seu aparelho reprodutor. 0 objetivo do presente trabalho foi investigar a morfologia e a biometria dos testículos, epidídimos e pênis, a biometria corporal e dos caracteres sexuais secundários. Foram utilizados 27 machos adultos desta espécie, visando contribuir com ações de preservação em cativeiro, controle populacional e pesquisas científicas, além de comparações interespecíficas. A identificação sexual pelo comprimento da terceira garra foi efetiva e os espécimes apresentaram desenvolvimento corporal harmônico e positivo entre massa, carapaça, plastrão e altura, com tendência unimodal e maior frequência de comprimento 
máximo de carapaça em $15,0 \mathrm{~cm}$. Testículos e epidídimos apresentaram semelhança biométrica entre os antímeros e estrutura anatômica e histológica semelhantes à de outras espécies de quelônios e mamíferos, excetuando-se pelo tipo de epitélio. Os achados sugerem haver morfologia conservada entre os cágados e homologia em relação aos mamíferos. A semelhança histológica com os órgãos reprodutivos de outros amniotas, incluindo os humanos, pode dar ensejo a estudos científicos e comparativos, essenciais para estabelecimento de estratégias de conservação em répteis.

TERMOS DE INDEXAÇÃO: Morfologia, biometria, órgãos reprodutivos, Trachemys scripta elegans, Brasil, testículos, pênis, epidídimos, tartaruga, répteis.

\section{INTRODUCTION}

Introduction of invasive species is a major threat to several chelonians worldwide (Buhlmann et al. 2002) and a serious danger to maintenance of biological diversity (Primack \& Rodrigues 2001). This has been observed with Trachemys scripta elegans (Wied 1839), also known as American water tiger or red-eared slider, a species native to North America geographically distributed from Eastern United States to Northeastern Mexico (Ernst \& Barbour 1989 apud Vieira \& Costa 2006). Illegal and indiscriminate trade has made this species the most commercialized in Brazil; however, in Cerrado areas, it is an exotic and invasive species that, when released in ponds, lakes, rivers and other bodies of water, threatens local biodiversity and endangers native species through competition or genetic extinction resulting from hybridization (Fonseca 2001).

Interest in studies addressing reproduction of reptiles has increased because of conservation needs. The following genera naturally occur in Brazil: Trachemys dorbignyi and Trachemys adiutrix, Podocnemis unifilis and Podocnemis erythrocephala, Phrynops hilari, Phrynops williamsi and Phrynops geoffroanus, Kinosternon scorpioides. Environmental factors and selection pressure have caused local adaptations and specific conditions in natural populations (Schluter 2000) that led to morphological and genetic variations within and between species and subspecies of the genus Trachemys (Daza \& Paez 2007, Batistella 2008, Readel et al. 2008). In this genus, differences in body size and shape resulting from different habitats are observed among monitored populations (Pérez et al. 2010). For instance, larger females have been found in areas where hunting is less intense (Close \& Seigel 1997, Daza \& Paez 2007) and where there is greater rainfall (Close \& Seigel 1997).

Lack of information on reptiles hinders population control, because their morphology, anatomy and physiology are unique. Therefore, knowledge about the anatomy and physiology of slider turtles is essential for understanding the evolutionary processes, conducting conservation studies, and preserving wild and exotic species (Cooke et al. 2013), as well as for the prevention and control of introduced species (Hulme 2006, Keller et al. 2008), and can also serve as a reference for areas such as animal surgery, clinic and rehabilitation (Aversi-Ferreira et al. 2005) and provide subsidies for comparative analysis with other species (Moura et al. 2007). In newly hatched Trachemys dorbignyi, and up to approximately two or three years of age, anatomical follow-up of the gonads is fundamental (Malvasio et al. 1999), and for Caretta caretta, histological assessment is also necessary (Yntema \& Mrosovsky 1980 apud Malvasio et al. 1999). Secondary sexual characters such as elongated forelimb claws, long and broad tail with extended cloacal opening, and carapace edge develop rapidly during sexual maturation and are frequently used for identification of mature males (Thomas 2002, Bager 2003, Ernst \& Barbour 1989 apud Vieira \& Costa 2006, Readel et al. 2008), whereas in females sexual maturity is evidenced by presence of yellow vitellogenic follicles, vascularization greater than three millimeters, traces of ovulation, and eggs in the oviduct (Hamann et al. 2003, Wyneken 2004). Nevertheless, the minimum sizes indicative of sexual maturity in ocean turtles vary according to area, habitat, sex, and species (Perez et al. 2010), whereas morphophysiological changes observed in the testes, epididymides, and vas deferens are influenced by age until sexual maturity is achieved, and as well as between breeding seasons (Wyneken 2001).

The testes present fusiform morphology are bright yellowish or rosy gray, and attach to the peritoneum through the mesorchium (Lutz et al. 2003). The penis is retractable, composed by a urethral groove (sulcus spermaticus) interspersed with corpora cavernosa and located on the base of the cloaca (Wyneken 2001).

Studies addressing the biometry and morphology of Trachemys scripta elegans are scarce and restricted to the animals in their natural habitat, and there is no research on the reproduction anatomy of males reared in the Cerrado region. In this context, the objective of this study is to describe the biometry and morphology of the male reproductive organs of this species raised in this unique biome so that this information can be used in reproductive biology aimed at preservation actions in captivity, population control, and scientific research, in addition to enabling interspecific comparisons.

\section{MATERIALS AND METHODS}

Animals. Twenty-seven adult males of Trachemys scripta elegans (Wied 1839) (Testudines: Emydidae) from the Wild Animal Triage Center (CETA) of the Tiete Ecological Park, Guarulhos, Sao Paulo state, Brazil (2329'23.15" S; 46³1'10.90” W) (IBAMA licenses no. $136 / 2011$ and $048 / 2012$ ) were anesthetized with a combination of xylazine hydrochloride (40mg kg-1) and ketamine (60 $\mathrm{mg} \mathrm{kg}^{-1}$ ), administered intraperitoneally, and euthanized using an infusion of propofol ( $50 \mathrm{mg} \mathrm{kg}^{-1}$ ) in the spinal canal through the atlanto-occipital joint. Subsequently, the animals were frozen and sent in Styrofoam boxes containing dry ice to the Laboratory of Anatomy of Domestic and Wild Animals (LAADS) of "Universidade Federal do Vale do São Francisco" (Univasf) in Petrolina, Pernambuco state (9²3'34"S; $40^{\circ} 30^{\prime} 28^{\prime \prime} \mathrm{W}$ ). This study was approved by SISBIO/IBAMA (protocol no. 38601-1) and the Ethics Committee on Animal Use (CEUA) of Univasf (protocol no. 0002/160412, 0003/160412, and 0004/160412).

Biometry of secondary sexual characters and tail. At LAADS, after thawing, the following morphometric measures were taken: body mass (BM); maximum carapace length (MCL) and width (MCW); maximum plastron length (MPL) and width (MPW), and shell height (HGT); 3rd claw length (CWL), pre-cloacal tail length (PrCTL), post-cloacal tail length (PoCTL), and full tail length (FTL). $\mathrm{BM}(\mathrm{g})$ was determined using a digital precision analytical scale (Bioprecisa ${ }^{\circledR}$, Labmais Ltda., Curitiba/PR, Brazil); MCL, MCW, MPL, MPW and HGT $(\mathrm{cm})$ were measured using a millimeter measuring tape; CWL, PrCTL, PoCTL and FTL measures $(\mathrm{cm})$ were taken using 
a caliper with millimeter accuracy. MCL was measured in a straight line in the medial part from the anterior edge of the nuchal shield to the end of the suture between the supracaudal shields; MCW was taken as the greatest distance between the marginal shields from side to side; MPL was characterized as a measure taken from the suture between the gular scute, in the furthermost cranial part to the suture between the anal scute in the furthermost caudal part; MPW was measured from the suture between the pectoral and abdominal scute to the point where they meet the marginal shields of both antimeres; HGT was calculated by measuring the greatest distances established between the plastron and the carapace (Malvasio et al. 1999). CWL was assessed by measuring the length in a straight line from the base to the end of the third finger of the right forelimb; when this claw was worn or broken, the left antimere was evaluated. PrCTL was assessed by measuring the distance between the tail base and the cloacal opening; PoCTL was evaluated by measuring the distance between the cloacal opening and the tail end; FTL corresponded to the sum of the last two measures.

Subsequently, the specimens were sexed according to the following methodology: individuals with MCL $\geq 13.0 \mathrm{~cm}$ and presence of elongated $3^{\text {rd }}$ finger forelimb claw were classified as males, whereas those in which these characteristics were not observed were classified as females (Bager 2003). Sex of the study specimens was later confirmed by dissection.

Biometry and morphology of reproductive organs. The bridge structure that connects the carapace to the plastron was split using a hammer and chisel, and the plastron was removed showing the internal organs. After that, the intestines, liver, stomach, and heart were removed using fine-tip scissors, exposing the urogenital system, thus allowing sex confirmation: presence of ovaries with or without follicles and oviducts in females and presence of testes, epididymides and penis in males. The reproductive organs were removed from the coelomic cavity and submitted to biometry (weight, length, width, and thickness). The weight ( $\mathrm{g}$ ) of each organ was obtained using a digital precision analytical scale $(0.001 \mathrm{~g})$ and the morphometric measures were taken using a caliper with millimeter accuracy. Tissue fragments of the reproductive organs were collected for routine histological processing, hematoxylin and hematoxylin-eosin staining (HE), and subsequent evaluation under light microscopy for morphological description. Sex maturation stages were identified in males by presence of spermatozoa in the seminiferous tubules and/or epididymides or by presence of differentiated spermatocytes and mature spermatids in the seminiferous tubules.

Statistical analysis. Data (mean + S.E.M.) were submitted to analysis of variance (ANOVA) with application of the post hoc Student's $t$-test $(p<0.05)$. The Pearson correlation coefficient was used in the analysis between the assessed numerical parameters processed in Assistat 7.6 Beta $^{\circledR}$ software.

\section{RESULTS}

Biometry of the body, secondary sexual characters, and tail

The following mean (minimum/maximum) values were obtained: $\mathrm{BM}=489.27+29.84 \mathrm{~g}(316.60 / 992.00)$, $\mathrm{MCL}=15.51+0.33 \mathrm{~cm}(11.90 / 18.90), \mathrm{MCW}=12.19+0.21 \mathrm{~cm}$ $(10.30 / 15.00), \mathrm{MPL}=14.11+0.27 \mathrm{~cm}(12.00 / 15.50)$, $\mathrm{MPW}=9.27+0.21 \mathrm{~cm}(6.20 / 12 / 20), \mathrm{HGT}=5.36+0.11 \mathrm{~cm}$ (4.10/6.50). Frequency distribution by size classes showed unimodal tendency with higher frequency of MCL at $15 \mathrm{~cm}$ (Fig.1).

The following mean (minimum/maximum) values were also obtained: PrCTL $=1.69+0.14 \mathrm{~cm}(0.70 \mathrm{~cm} / 3.20 \mathrm{~cm})$,
PoCTL $=2.19+0.10 \mathrm{~cm}(0.80 \mathrm{~cm} / 2.80 \mathrm{~cm}), \mathrm{FTL}=4.33+0.24 \mathrm{~cm}$ $(2.00 \mathrm{~cm} / 5.90 \mathrm{~cm}), \mathrm{CWL}=1.51+0.05 \mathrm{~cm}(0.90 \mathrm{~cm} / 1.80 \mathrm{~cm})$.

All male individuals presented spermatozoa in smears of the testicular fluid and/or in the epididymides, and their reproductive organs could be easily identified after opening of the coelom. No statistically significant differences $(p>0.05)$ were observed between right and left antimeres in the biometry of the reproductive organs (Table 1), and presented the following variations (minimum/maximum): $\mathrm{TWe}=0.05 / 1.28 \mathrm{~g}, \mathrm{TL}=0.50 / 1.60 \mathrm{~cm}, \mathrm{TWi}=0.50 / 1.40 \mathrm{~cm}$, TRT $=0.10 / 0.60 \mathrm{~cm}$.

Very high correlation $(p<0.01)$ was observed between the body biometric parameters, except for MCL and HGT, which presented significant correlation $(p<0.05)$. Regarding the tail, significant correlation $(\mathrm{p}<0.05)$ was found between PoCTL and FTL and very significant correlation $(p<0.01)$ was verified between PrCTL and FTL. CWL showed significant correlation $(p<0.05)$ with BM and MPL (Table 2$)$.

Table 3 shows the Pearson correlation $(r)$ between the biometric parameters of the body, secondary sexual characters, and testis. Very significant correlation $(p<0.01)$ was verified between BM and TWe, TL and TWi; between TWe and TL, TWi and TRT; between TL and TWi; between TWi and TRT. Significant correlation $(p<0.05)$ was found between HGT and TWe, TL and TWi, and between TL and TRT.

\section{T. scripta elegans}

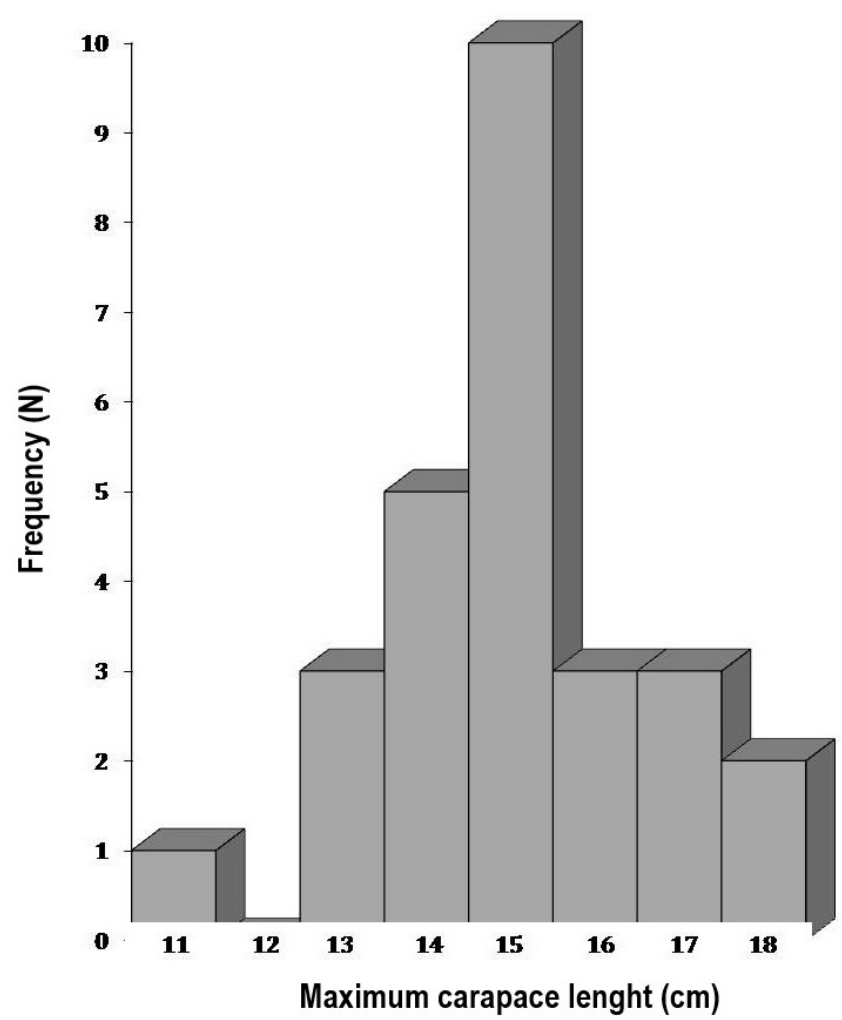

Fig.1. Frequency distribution of the maximum carapace length in males of Trachemys scripta elegans from the Wild Animal Triage Center (CETA) of the Tiete Ecological Park, Guarulhos, São Paulo state, Brazil. The graph shows unimodal tendency and higher frequency distribution of maximum carapace length at $15 \mathrm{~cm}$. 
Table 1. Biometry of the reproductive organs (mean +SEM) of male Trachemys scripta elegans from the Wild Animal Triage Center (CETA) of the Tiete Ecological Park, Guarulhos, São Paulo state, Brazil

\begin{tabular}{lllll}
\hline \multicolumn{1}{r}{ Antimere } & Weight $(\mathrm{g})$ & Length $(\mathrm{cm})$ & Width $(\mathrm{cm})$ & Thickness $(\mathrm{cm})$ \\
\hline Testis & & & & $0.31+0.06$ \\
$\quad$ Right & $0.28+0.06$ & $0.99+0.06$ & $0.75+0.05$ & $0.26+0.03$ \\
$\quad$ Left & $0.25+0.06$ & $0.97+0.06$ & & $0.30+0.04$ \\
Epididymis & & & $0.76+0.05$ & $0.32+0.03$ \\
$\quad$ Right & $0.58+0.06$ & $2.25+0.11$ & $0.76+0.06$ & $0.49+0.02$ \\
$\quad$ Left & $0.60+0.06$ & $2.27+0.11$ & $1.37+0.04$ &
\end{tabular}

Table 2. Pearson correlation ( $r$ ) between the biometric parameters of body and secondary sex characters of male Trachemys scripta elegans from the Wild Animal Triage Center (CETA) of the Tiete Ecological Park, Guarulhos, São Paulo state, Brazil

\begin{tabular}{|c|c|c|c|c|c|c|c|c|c|}
\hline & MCL & MCW & MPL & MPW & HGT & PoCTL & PrCTL & FTL & CWL \\
\hline $\mathrm{BM}$ & $0.59 * *$ & $0.69 * *$ & $0.73^{* *}$ & $0.65^{* *}$ & $0.54 * *$ & $-0.11^{\mathrm{ns}}$ & $-0.07^{\mathrm{ns}}$ & $-0.03^{\mathrm{ns}}$ & $-0.47^{*}$ \\
\hline MCL & ------ & $0.79 * *$ & $0.74^{* *}$ & $0.63^{* *}$ & $0.48^{*}$ & $-0.09^{n s}$ & $-0.35^{\mathrm{ns}}$ & $-0.24^{\mathrm{ns}}$ & $-0.30^{\mathrm{ns}}$ \\
\hline MCW & ------- & ------- & $0.88^{* *}$ & $0.83^{* *}$ & $0.50^{* *}$ & $-0.04^{\mathrm{ns}}$ & $-0.23^{\mathrm{ns}}$ & $-0.18^{\mathrm{ns}}$ & $-0.35^{\mathrm{ns}}$ \\
\hline MPL & ------- & ------- & ------- & $0.83^{* *}$ & $0.62^{* *}$ & $-0.10^{\mathrm{ns}}$ & $-0.15^{\mathrm{ns}}$ & $-0.11^{\mathrm{ns}}$ & $-0.38 *$ \\
\hline MPW & ------ & ------ & ------ & ------ & $0.56^{* *}$ & $-0.14^{\mathrm{ns}}$ & $-0.01^{\mathrm{ns}}$ & $-0.02^{\mathrm{ns}}$ & $-0.48^{*}$ \\
\hline HGT & ------ & --.-- & ------ & --.--- & ------ & $-0.02^{n s}$ & $-0.04^{\mathrm{ns}}$ & $-0.11^{\mathrm{ns}}$ & $-0.10^{\mathrm{ns}}$ \\
\hline PoCTL & ------ & ------ & ------- & ------ & ------ & ------ & $0.33^{\text {ns }}$ & $0.46^{*}$ & $-0.00^{\mathrm{ns}}$ \\
\hline PrCTL & ------ & ------ & ------- & ------ & ------- & ------- & ------ & $0.86^{* *}$ & $-0.11^{\mathrm{ns}}$ \\
\hline FTL & ------- & ------ & ------- & ------ & ------- & ------- & ------ & ------ & $-0.06^{\mathrm{ns}}$ \\
\hline CWL & ------- & ------- & ------ & ------ & ------ & ------ & ------ & ------ & ------ \\
\hline
\end{tabular}

* Statistically significant at $5 \%$ probability level $(p<0.05),{ }^{* *}$ statistically significant at $1 \%$ probability level $(p<0.01),{ }^{\text {ns }}$ not significant $(p>0.05)$; BM $=$ body mass, $\mathrm{MCL}=$ maximum carapace length, $\mathrm{MCW}=$ maximum carapace width, MPL = maximum plastron length, MPW = maximum plastron width, $\mathrm{HGT}=$ shell height, PrCTL = per-cloacal tail length, PoCTL = post-cloacal tail length, FTL = full tail length, CWL = 3rd claw length.

Table 3. Pearson correlation ( $r$ ) between the biometric parameters of body, secondary sex characters, and testis of male Trachemys scripta elegans from the Wild Animal Triage Center (CETA) of the Tiete Ecological Park, Guarulhos, São Paulo state, Brazil

\begin{tabular}{ccccc}
\hline & TWe & TL & TWi & TRT \\
\hline BM & $0.63^{* *}$ & $0.53^{* *}$ & $0.60^{* *}$ & $0.31^{\text {ns }}$ \\
MCL & $0.07^{\text {ns }}$ & $0.08^{\text {ns }}$ & $0.14^{\text {ns }}$ & $0.03^{\text {ns }}$ \\
MCW & $0.28^{\text {ns }}$ & $0.33^{\text {ns }}$ & $0.28^{\text {ns }}$ & $0.17^{\text {ns }}$ \\
MPL & $0.25^{\text {ns }}$ & $0.26^{\text {ns }}$ & $0.24^{\text {ns }}$ & $0.19^{\text {ns }}$ \\
MPW & $0.27^{\text {ns }}$ & $0.25^{\text {ns }}$ & $0.29^{\text {ns }}$ & $0.19^{\text {ns }}$ \\
HGT & $0.40^{*}$ & $0.40^{*}$ & $0.44^{*}$ & $0.31^{\text {ns }}$ \\
PoCTL & $0.12^{\text {ns }}$ & $0.11^{\text {ns }}$ & $0.13^{\text {ns }}$ & $0.11^{\text {ns }}$ \\
PrCTL & $0.11^{\text {ns }}$ & $-0.05^{\text {ns }}$ & $0.13^{\text {ns }}$ & $0.30^{\text {ns }}$ \\
FTL & $0.08^{\text {ns }}$ & $0.01^{\text {ns }}$ & $0.13^{\text {ns }}$ & $0.22^{\text {ns }}$ \\
CWL & $-0.26^{\text {ns }}$ & $-0.13^{\text {ns }}$ & $-0.30^{\text {ns }}$ & $-0.19^{\text {ns }}$ \\
TWe & ---- & $0.87^{* *}$ & $0.96^{* *}$ & $0.56^{* *}$ \\
TL & ---- & ---- & $0.85^{* *}$ & $0.45^{*}$ \\
TWi & ---- & ---- & ---- & $0.67^{* *}$
\end{tabular}

* Statistically significant at $5 \%$ probability level $(p<0.05)$, ${ }^{* *}$ statistically significant at $1 \%$ probability level $(p<0.01)$, ns not significant $(p>0.05)$; $\mathrm{BM}=$ body mass, $\mathrm{MCL}=$ maximum carapace length, $\mathrm{MCW}=$ maximum carapace width, MPL = maximum plastron length, $\mathrm{MPW}=$ maximum plastron width, HGT =shell height, PrCTL = per-cloacal tail length, PoCTL $=$ post-cloacal tail length, FTL $=$ full tail length, $\mathrm{CWL}=3 \mathrm{rd}$ claw length, TWe $=$ testis weight, $\mathrm{TL}=$ testis length, $\mathrm{TWi}=$ testis width, TRT $=$ thickness of the right testis.
No statistically significant correlation $(p>0.05)$ was observed between the biometric parameters of body, secondary sex characters, and epididymis of male individuals except for very significant correlation $(p<0.01)$ between EWe and EL, EWi and TRE, between EL and EWi, and between EWi and TRE (Table 4).

Regarding the penis, very significant correlation $(p<0.01)$ was verified between BM and PWe and PL; between MCL and PWe and PL; between PoCTL and PT, and significant correlation $(p<0.05)$ was found between PWe and MCW, MPL, HGT and CWL; between PL and MPL, HGT, PWe and PWi; between PWi and HGT (Table 5).

Gross anatomical description of the reproductive organs

The reproductive tract was located in the caudal part of the coelomic cavity, caudally to the lungs, and communicated with the external environment through the cloaca (Fig.2A). It was composed of a pair of testes, epididymides and vas deferens, and a penis (Fig.2B). The testes were located in both antimeres, were oval, bright yellowish, and positioned cranially to the epididymides and caudally to the kidneys (Fig.2A). It was not possible to identify the testicular parenchyma and mediastinum in the longitudinal section. The epididymides were located in both antimeres, consisted of delicate, grayish, convoluted tubes that elongated caudally and connected to the medium caudal end of each testis through the mesorchium that attached them to the dorsal body wall (Fig.2A,B). The epididymides were joined to the vas deferens, 
which penetrated the cloacal region near the opening base of the urinary vesicle, more precisely in the spermatic sulcus located at the base of the penis (Fig.2B).

Table 4. Pearson correlation ( $r$ ) between the biometric parameters of body, secondary sex characters, and epididymis of male Trachemys scripta elegans from the Wild Animal Triage Center (CETA) of the Tiete Ecological Park, Guarulhos, São Paulo state, Brazil

\begin{tabular}{ccccc}
\hline & EWe & EL & EWi & TRE \\
\hline BM & $-0.33^{\text {ns }}$ & $-0.32^{\text {ns }}$ & $-0.38^{\text {ns }}$ & $-0.16^{\text {ns }}$ \\
MCL & $0.15^{\text {ns }}$ & $0.05^{\text {ns }}$ & $0.07^{\text {ns }}$ & $0.02^{\text {ns }}$ \\
MCW & $0.14^{\text {ns }}$ & $0.14^{\text {ns }}$ & $0.10^{\text {ns }}$ & $0.18^{\text {ns }}$ \\
MPL & $0.19^{\text {ns }}$ & $0.13^{\text {ns }}$ & $0.13^{\text {ns }}$ & $0.11^{\text {ns }}$ \\
MPW & $0.12^{\text {ns }}$ & $0.23^{\text {ns }}$ & $0.15^{\text {ns }}$ & $0.05^{\text {ns }}$ \\
HGT & $0.13^{\text {ns }}$ & $0.29^{\text {ns }}$ & $0.09^{\text {ns }}$ & $-0.13^{\text {ns }}$ \\
PoCTL & $0.04^{\text {ns }}$ & $-0.14^{\text {ns }}$ & $-0.01^{\text {ns }}$ & $0.16^{\text {ns }}$ \\
PrCTL & $-0.18^{\text {ns }}$ & $-0.05^{\text {ns }}$ & $-0.09^{\text {ns }}$ & $-0.04^{\text {ns }}$ \\
FTL & $-0.28^{\text {ns }}$ & $-0.07^{\text {ns }}$ & $-0.21^{\text {ns }}$ & $-0.20^{\text {ns }}$ \\
CWL & $0.28^{\text {ns }}$ & $0.30^{\text {ns }}$ & $0.22^{\text {ns }}$ & $0.09^{\text {ns }}$ \\
EWe & ------ & $0.66^{* *}$ & $0.86^{* *}$ & $0.68^{* *}$ \\
EL & ------ & ------ & $0.65^{* *}$ & $0.24^{\text {ns }}$ \\
EWi & ------ & ------ & ---- & $0.50^{* *}$
\end{tabular}

* Statistically significant at $5 \%$ probability level $(p<0.05),{ }^{* *}$ statistically significant at $1 \%$ probability level $(p<0.01)$, ns not significant $(p>0.05)$; $\mathrm{BM}=$ body mass, $\mathrm{MCL}=$ maximum carapace length, $\mathrm{MCW}=$ maximum carapace width, $\mathrm{MPL}=$ maximum plastron length, $\mathrm{MPW}=$ maximum plastron width, HGT =shell height, PrCTL = per-cloacal tail length, PoCTL $=$ post-cloacal tail length, FTL $=$ full tail length, $\mathrm{CWL}=3$ rd claw length, $\mathrm{EWe}=$ epididymis weight, $\mathrm{EL}=$ epididymis length, $\mathrm{EWi}=$ epididymis width, TRE $=$ thickness of the right epididymis.

Table 5. Pearson correlation ( $r$ ) between the biometric parameters of body and penis of male Trachemys scripta elegans from the Wild Animal Triage Center (CETA) of the Tiete Ecological Park, Guarulhos, Sao Paulo state, Brazil

\begin{tabular}{ccccc}
\hline & PWe & PL & PWi & PT \\
\hline BM & $0.68^{* *}$ & $0.51^{* *}$ & $0.31^{\mathrm{ns}}$ & $0.24^{\mathrm{ns}}$ \\
MCL & $0.56^{* *}$ & $0.50^{* *}$ & $0.22^{\mathrm{ns}}$ & $0.30^{\mathrm{ns}}$ \\
MCW & $0.43^{*}$ & $0.34^{\mathrm{ns}}$ & $-0.01^{\mathrm{ns}}$ & $0.26^{\mathrm{ns}}$ \\
MPL & $0.40^{*}$ & $0.42^{*}$ & $0.17^{\mathrm{ns}}$ & $0.27^{\mathrm{ns}}$ \\
MPW & $0.42^{*}$ & $0.30^{\mathrm{ns}}$ & $0.09^{\mathrm{ns}}$ & $0.34^{\mathrm{ns}}$ \\
HGT & $0.44^{*}$ & $0.39^{*}$ & $0.43^{*}$ & $0.19^{\mathrm{ns}}$ \\
PoCTL & $-0.12^{\mathrm{ns}}$ & $-0.15^{\mathrm{ns}}$ & $-0.22^{\mathrm{ns}}$ & $-0.53^{* *}$ \\
PrCTL & $0.09^{\mathrm{ns}}$ & $-0.14^{\mathrm{ns}}$ & $0.05^{\mathrm{ns}}$ & $-0.09^{\mathrm{ns}}$ \\
FTL & $0.04^{\mathrm{ns}}$ & $-0.20^{\mathrm{ns}}$ & $0.07^{\mathrm{ns}}$ & $-0.08^{\mathrm{ns}}$ \\
CWL & $-0.46^{*}$ & $-0.09^{\mathrm{ns}}$ & $0.02^{\mathrm{ns}}$ & $-0.07^{\mathrm{ns}}$ \\
PWe & ----- & $0.44^{*}$ & $0.34^{\mathrm{ns}}$ & $0.11^{\mathrm{ns}}$ \\
PL & ------ & ----- & $0.46^{*}$ & $0.23^{\mathrm{ns}}$ \\
PWi & ------ & ----- & ----- & $0.21^{\mathrm{ns}}$
\end{tabular}

* Statistically significant at $5 \%$ probability level $(p<0.05),{ }^{* *}$ statistically significant at $1 \%$ probability level $(p<0.01)$, ns not significant $(p>0.05)$; $\mathrm{BM}=$ body mass, $\mathrm{MCL}=$ maximum carapace length, $\mathrm{MCW}=$ maximum carapace width, MPL = maximum plastron length, $\mathrm{MPW}=$ maximum plastron width, HGT = shell height, $\operatorname{PrCTL}=$ per-cloacal tail length, PoCTL $=$ post-cloacal tail length, FTL $=$ full tail length, $\mathrm{CWL}=3$ rd claw length, $\mathrm{PWe}=$ penis weight, $\mathrm{PL}=$ penis length, $\mathrm{PWi}=$ penis width, $\mathrm{PT}=$ penis thickness.
The penis was a single, retractile organ with copulatory function only, positioned longitudinally from the ventral wall of the cloaca. The ureters were short and opened directly into the cloaca, whereas the ductus deferens brought the spermatozoa to the urethral groove at the base of the penis. The organ was divided into a root that formed its base and had two structures, one on each side, involved in the processes of eversion and retraction; the body was composed of two corpora cavernosa interspersed with a spermatic sulcus and the glans or terminal portion (Fig.3).
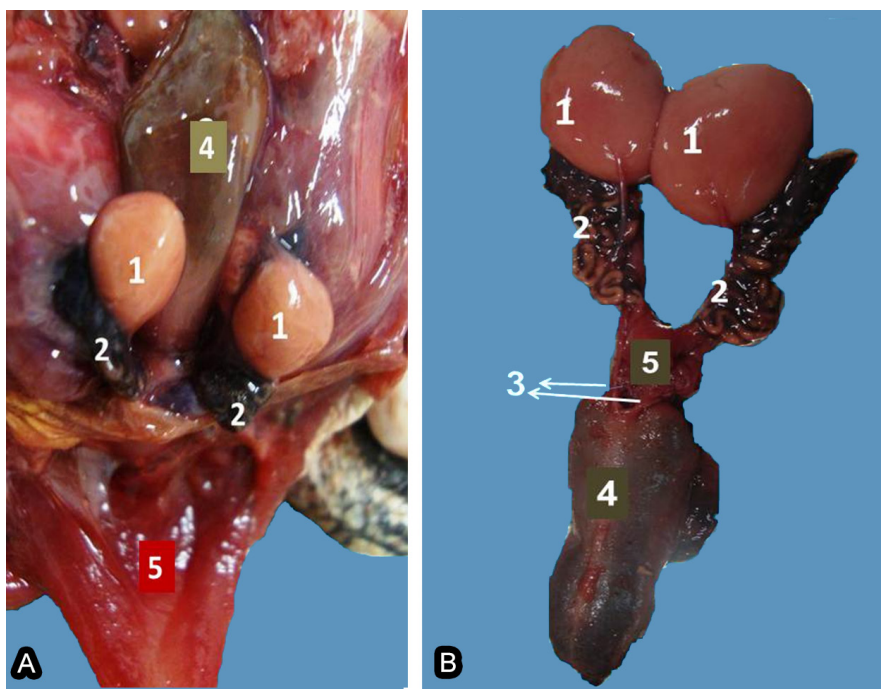

Fig.2. Reproductive tract of male Trachemys scripta elegans from the Wild Animal Triage Center (CETA) of the Tiete Ecological Park, Guarulhos, São Paulo state, Brazil. (A) View of the dorsal-caudal part of the coelom and anatomic aspect of the testes (1), epididymides (2), vas deferens - ductus deferens (3), penis (4), and cloaca (5). (B) Reproductive organs after removal from the coelomic cavity.

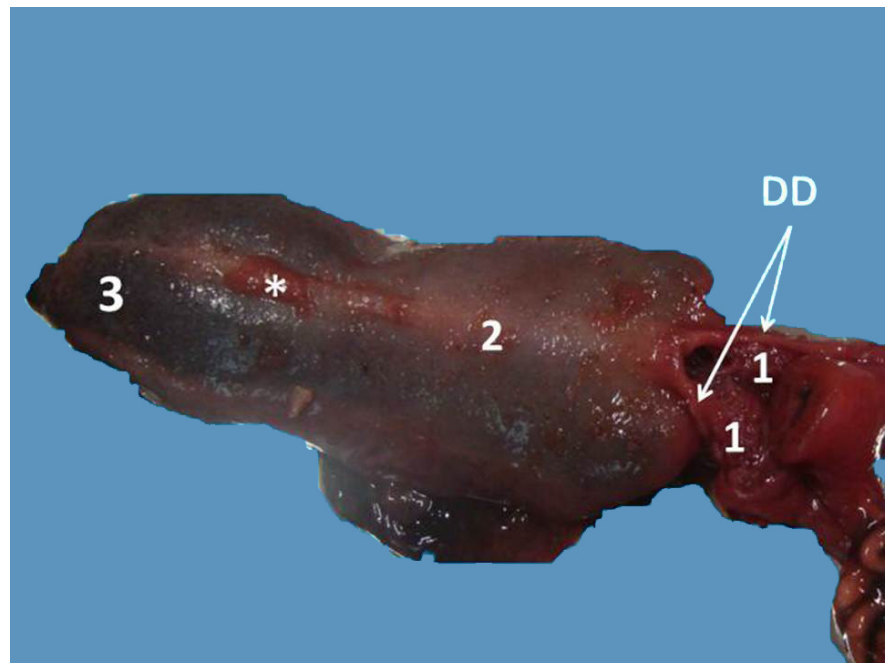

Fig.3. Penis of pubescent Trachemys scripta elegans from the Wild Animal Triage Center (CETA) of the Tiete Ecological Park, Guarulhos, São Paulo state, Brazil: root (1), corpora cavernosa (2), glans (3), and urethral groove - sulcus spermaticus $\left(^{*}\right)$. 


\section{Morphological description of the reproductive organs}

The testis was coated with a layer of dense connective tissue, rich in collagen fibers - the tunica albuginea, which provided support and protection to the organ and subdivided it into lobes filled with seminiferous tubules (Fig.4A,B), which were of varied shapes and sizes and internally lined by stratified epithelium, the seminiferous epithelium, composed of two categories of cells: support (Sertoli) and spermatogenic, with the latter represented by undifferentiated $(\mathrm{Au})$ and differentiated $(\mathrm{Ad})$ type A spermatogonia; primary spermatocytes at pre-leptotene (PL), leptotene (L), pachythene (PC) and zygotene (Z) stages, round spermatids (R) and spermatozoa (S) in the lumen of the seminiferous tubule (Fig.4C).

Under light microscopy, three regions of the epididymis were identified: head, body and tail. The head showed ductuli efferentes and the epididymal duct, interspersed with loose connective tissue, smooth muscle tissue, and blood vessels (Fig.5A); in the body, the epididymal duct presented a smaller diameter than that in the tail region, which had more spermatozoa. The ductuli efferentes consisted of a canalicular complex surrounded by a thin layer of smooth muscle tissue and supported by connective tissue, which emerged from a testicular network at the capitate end of the testis in number ranging from 3 to 10 . The epithelium of the ductuli efferentes was of simple columnar type, and the lumen showed irregular contours and was empty (Fig.5B).

The epididymal duct was delimited by a layer of loose connective tissue interspersed with smooth muscle tissue and showed simple columnar-type epithelium composed of principal and basal cells in contact with the basal membrane (Fig.6). The principal cells were elongated, heterogeneous in shape, and contained a large amount of cytoplasm and
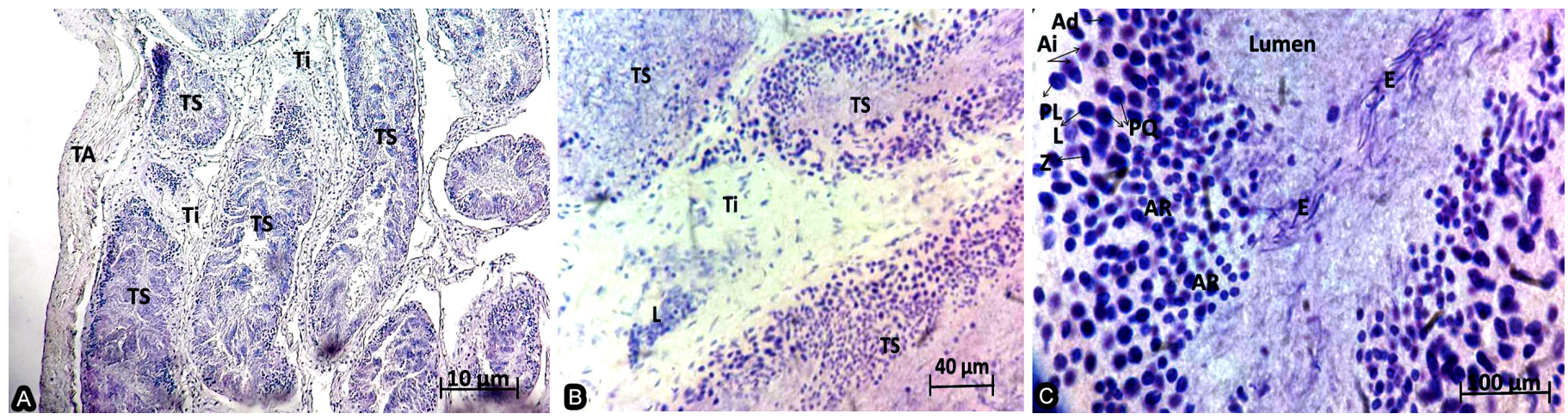

Fig.4. Testis of Trachemys scripta elegans from the Wild Animal Triage Center (CETA) of the Tiete Ecological Park, Guarulhos, São Paulo state, Brazil. (A) Tunica albuginea (TA) composed of dense connective tissue, rich in collagen fibers and seminiferous tubules (TS) surrounded by interstitial tissue (Ti) composed of loose vascular connective tissue. HE, bar=10 $\mu$ m. (B) Leydig cells (L) present in the interstitial tissue (Ti) surrounding the seminiferous tubules (TS). HE, bar $=40 \mu \mathrm{m}$. (C) Seminiferous epithelium at stage V of the seminiferous epithelium cycle (SEC) (Courot et al. 1970) with undifferentiated (Ai) and differentiated (Ad) type A spermatogonia; primary spermatocytes at pre-leptotene (PL), leptotene (L), zygotene (Z), and pachytene (PQ) stages; round spermatids (AR) and presence of spermatozoa (E) in the lumen of the seminiferous tubule. HE, bar=100 $\mu \mathrm{m}$.
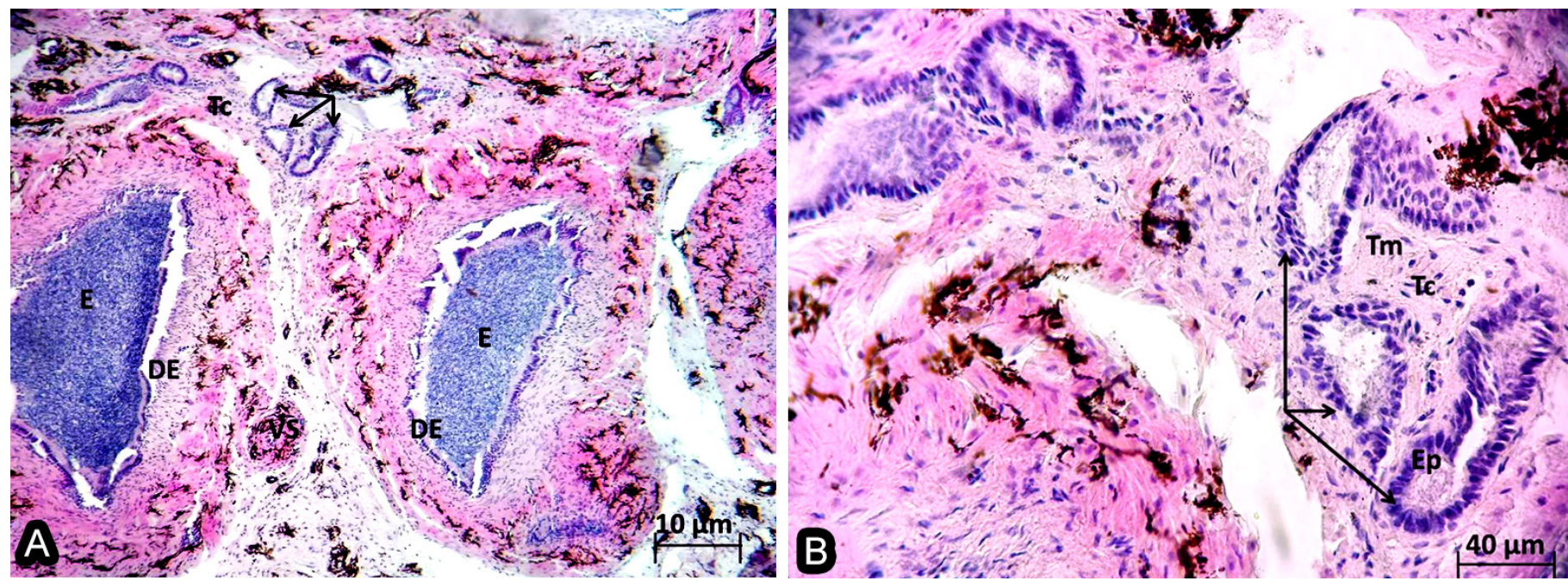

Fig.5. Epididymis of Trachemys scripta elegans from the Wild Animal Triage Center (CETA) of the Tiete Ecological Park, Guarulhos, São Paulo state, Brazil. Epididymal duct (DE) filled with spermatozoa (E), ductuli efferentes (arrow) and blood vessels (VS) located in the connective tissue (Tc). HE, bar=10 $\mu \mathrm{m}$. (B) Ductuli efferentes (arrow) surrounded by loose connective tissue (Tc) and a thin layer of smooth muscle tissue (Tm), and coated with simple columnar epithelium (Ep). HE, bar=40 $\mu \mathrm{m}$. 
nucleus present in the basal pole, whereas the basal cells were flattened and located near the basal membrane of the duct, whose lumen contained a large number of spermatozoa (Fig.6). The epididymal duct continued along the body and tail of the epididymis, from which the vas deferens originated.

Histologically, the penis consisted of two corpora cavernosa around the central sulcus spermaticus (Fig.7A). The wall of the erectile body contained collagen fibers arranged in several alternate layers - the fibers were either parallel or perpendicular to the longitudinal axis of the organ (Fig.7B),

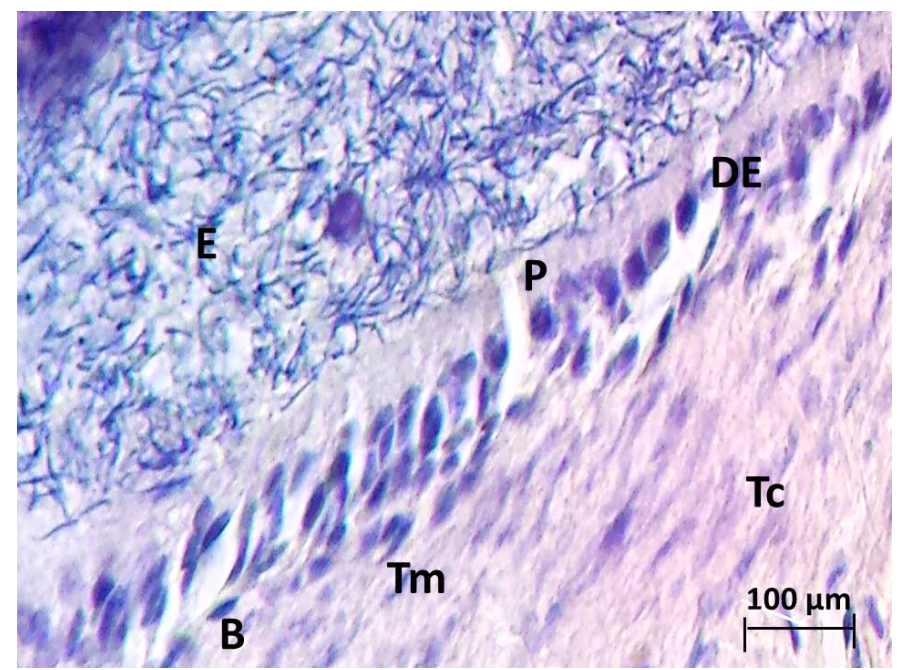

Fig.6. Epididymis of Trachemys scripta elegans from the Wild Animal Triage Center (CETA) of the Tiete Ecological Park, Guarulhos, São Paulo state, Brazil. Epididymal duct (DE) surrounded by simple columnar epithelium with principal (P) and basal (B) cells, surrounded by a thin layer of loose connective tissue (Tc) interspersed with smooth muscle tissue (Tm) and with presence of large number of spermatozoa (E) in its tubular lumen. HE, bar $=100 \mu \mathrm{m}$. and contained a groove that, during erection, formed a sulcus through which the spermatozoa was transported.

\section{DISCUSSION}

To the best of our knowledge, this is the first study to describe the male reproductive system of Trachemys scripta elegans (Testudines: Emydidae) based on biometric and morphological data. The objective was to analyze these characteristics in animals from the Wild Animal Triage Center (CETA) of the Tiete Ecological Park and make intra- and inter-specific comparisons. It is worth noting that previous studies addressing the reproductive biology of these slider turtles have described only their reproductive behavior ( Sousa et al. 2014) and the effect of temperature on sex determination (Vogt \& Bull 1982, Valenzuela et al. 1997).

Mean BM values of turtle sliders from the Wild Animal Triage Center (CETA) of the Tiete Ecological Park were similar to those of other specimens of the same origin described by Gradela et al. (2017) and of Trachemys scripta elegans assessed in Brasília/DF (Vieira \& Costa 2006), higher than those of Kinosternon scorpioides (Carvalho et al. 2010), and lower than those of Trachemys dorbigni (Silveira et al. 2012), whereas the minimum and maximum BM values were similar to the minimum and lower than the maximum values found for T. dorbigni (Bager 2003). Body development occurred in a harmonious and positive way between mass, carapace, plastron and height, differing from the findings reported in the study by Gradela et al. (2017), in which uniformity in body development occurred positively only between carapace and plastron, and height was correlated only with MPL. In this study, the body biometry was slightly higher than that reported for the same species in the survey by Vieira \& Costa (2006) except for MCW, lower than T. dorbignyi except for MPW and HGT (Silveira et al. 2012), and T. dorbignyi for all measures (Bager et al. 2010). The frequency of distribution by size classes was unimodal, similarly to that of T. scripta (Gibbons

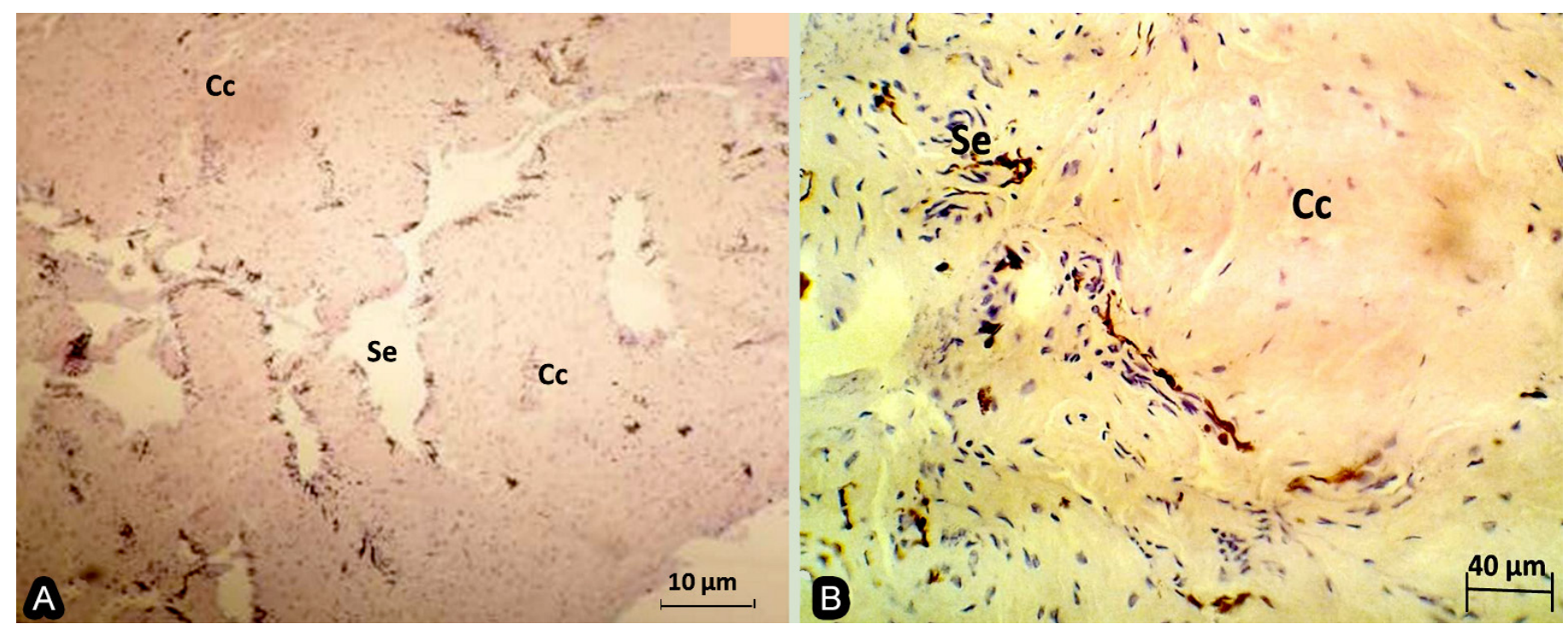

Fig.7. Penis of Trachemys scripta elegans from the Wild Animal Triage Center (CETA) of the Tiete Ecological Park, Guarulhos, São Paulo state, Brazil. (A) Corpus cavernosum (Cc) and urethral groove (sulcus spermaticus) (Se). HE, bar=10 $\mu$ m. (B) Detail of collagen fibers of corpus cavernosum and sulcus spermaticus. HE, bar= $40 \mu \mathrm{m}$. 
\& Greene 1990 apud Silveira et al. 2012, Lovich et al. 1990 apud Silveira et al. 2012, Gradela et al. 2017) and T. dorbignyi (Bager et al. 2010, Bujes et al. 2011, Silveira et al. 2012).

Secondary sexual characters, represented by elongated claws and a greater tail-cloaca distance, assist with sex identification between male and female turtles (Readel et al. 2008, Pérez et al. 2010), because the development of these characters occurs rapidly during male maturation (Gibbons \& Greene 1990 apud Silveira et al. 2012, Gibbons \& Lovich 1990 apud Vieira \& Costa 2006, Dyce et al. 1997, Duarte et al. 2011). In addition, studies have indicated that males show greater PrCTL compared with females (Readel et al. 2008, Bujes et al. 2011, Silveira et al. 2012), which may be useful in sex identification especially in populations that vary in size according to sexual maturity, because dissection and histology of the gonads may not be feasible, particularly in the case of endangered species or for long-term studies (Readel et al. 2008). In the present study, identification of the males by the 3rd claw length was effective, corroborating the findings of studies addressing Trachemys dorbignyi (Thomas 2002, Bager 2003, Ernst \& Barbour 1989 apud Vieira \& Costa 2006, Readel et al. 2008, Cabrera 1998) and Trachemys scripta from Illinois, USA (Readel et al. 2008) and contrasting with the results of the research on Trachemys adiutrix (Batistella 2008). Regarding the measures of the tail, positive correlation was observed between FTL and PrCTL $(r=0.86 ; p<0.01)$ and PoCTL $(r=0.46$; $p<0.05$ ), whereas very high negative correlation was found between PT and PoCTL $\left(r=-0.53^{* *} ; p<0.01\right)$.

In slider turtles male, the sexual structures were represented by a pair of testes, epididymides and vas deferens, and a penis located caudally in the coelom. These findings were similar to those reported for reptiles and vertebrates in general (Ashley 1969) and other species of turtles (Malvasio et al. 1999, Wyneken 2001, Carvalho et al. 2010). However, the absence of attached glands contrasted with mammals (Hafez \& Hafez 2004), but was similar to Kinosternon scorpioides (Carvalho et al. 2010).

Puberty in male slider turtles begins when the testes start to produce high concentrations of testosterone, which results in the development of secondary sexual characteristics and maturity of the seminiferous tubules, with onset of spermatogenesis (Wibbels et al. 1991 apud Gomes et al. 2006). All male individuals showed presence of spermatozoa in smears of testis fluid and/or in the epididymal duct, thus being sexually mature, which seems to have contributed to the anatomical recognition of the male reproductive organs after opening the coelomic cavity, in agreement with Wyneken (2001). Wyneken observed that, in sexually mature ocean turtles, sexual dimorphism is anatomically visible with difference between ovaries and testes, whereas in Caretta caretta (Yntema \& Mrosovsky 1980 apud Malvasio et al. 1999) and Chelonia mydas (Rosa 2009, Kondak 2012), gross identification of gonads is not feasible for sex identification, and histological analysis is needed. Malvasio et al. (1999) highlighted that the possibility of gross identification of gonads constitutes an advantage, because sex identification through dissection is the simplest, fastest and least expensive method in cases where external sexual characters do not show dimorphism. Although sexual maturity is dependent on the interaction between environmental and genetic factors (Stearns \& Koella 1986 apud Readel et al. 2008), variation in size and maturation age may be observed within and between populations (Gibbons \& Green 1990 apud Silveira et al. 2012). Studies addressing other turtle species have demonstrated that testis size and weight were correlated with MPL (Gibbons 1968 apud Readel et al. 2008, Mitchell 1985 apud Readel et al. 2008 ), a fact not observed in the present study.

In the testes and epididymides, the biometric similarity between antimeres contrasted with that verified in mammals, in which the left testis tends to be larger than the right one (Dyce et al. 1997), but corroborated findings in Kinosternon scorpioides (Carvalho et al. 2010) and Phrynops geoffroanus (Cabral et al. 2011a) and also contrasted with Pelusios castaneus, which presented differences in the length of testis and epididymis between the antimeres (Olukole et al. 2014). Only five studies on the morphometric assessment of testis in turtles were found in the literature: two were conducted with newly hatchlings (Malvasio et al. 2005, 2012), precluding comparisons with the present study because of differences in age and species; one was performed in males of Trachemys scripta from Illinois, USA, which were mature with $\mathrm{CC}=9.8 \mathrm{~cm}, \mathrm{CG}>0.7 \mathrm{~cm}$, PrCTL $>1.3 \mathrm{~cm}$ and $\mathrm{MT}>0.06 \mathrm{~g}$ (Readel et al. 2008), similarly to the present research; two were conducted with P. geoffroanus (Cabral et al. 2011a) and $P$. castaneus (Olukole et al. 2014). However, none of these authors established correlations between testicular, epididymal or penile biometry and biometry of the body and secondary sexual characters. Only Rosa (2009), investigating C. mydas, established correlation between the measures of curvilinear carapace length and testis linear length, and verified that this correlation was low and that there was no concomitant growth in length between carapace and gonads, as observed in the present survey. Bondioli et al. (2007) associated this fact with the possible genetic variability within the same population, even in cases where there is probable common origin of the entire sample. In this study, the variables associated with carapace and plastron showed no correlation with biometry of the gonads, and correlation was only observed between biometry of the testes and BM, and HGT and among the testis parameters.

Synoptic relationship between the testes and epididymides and the kidneys was similar to that verified for T. dorbignyi (Malvasio et al. 1999), K. scorpioides (Carvalho et al. 2010), and P. geoffroanus (Cabral et al. 2011a), and presence of the tunica albuginea corroborated the findings on $K$. scorpioides (Carvalho et al. 2010); P. geoffroanus (Cabral et al. 2011a), P. expansa, and P. unifilis (Malvasio et al. 2012). Yellowish testes have been described in ocean turtles (Lutz et al. 2003), K. scorpioides (Carvalho et al. 2010), and other Testudines (Goulart 2004), but contrasted with whitish testes on P. geoffroanus (Cabral et al. 2011a), in which macroscopic differentiation between testis parenchyma and mediastinum was also not observed.

Reptilians were the first amniotes to evolve from the aquatic environment to the terrestrial environment. In order to do so, many of their reproductive characteristics needed to be changed, among them the presence of tubular testes supported by Sertoli cells and of epididymis responsible for the storage of spermatozoa (Gribbins et al. 2006). This evolution enabled the produced spermatozoa to be protected, stored and deposited safely in the female reproductive tract, rather than being released into the inhospitable terrestrial environment. The microscopic structure of the testes of the slider turtles 
investigated, composed of seminiferous tubules of various sizes and shapes, with epithelium comprising spermatogenic and Sertoli cells, and interstice formed by loose connective tissue, Leydig cells, and blood vessels, was similar to that described in mammals (Junqueira \& Carneiro, 2011) and other chelonians (Danni \& Alho 1985 apud Malvasio et al. 1999, Wibbels et al. 1991 apud Gomes et al. 2006, Malvasio et al. 2012, Sousa et al. 2014).

Although the testes of reptiles contain seminiferous tubules filled with seminiferous epithelium, similar to those of mammals and birds, most temperate reptiles are seasonal reproducers (Gribbins et al. 2003). Therefore, germ cell development strategies in turtles are very different from that of other amniotes (Gribbins et al. 2003, Gribbins 2011), because these cells develop as the only temporary population in the testis, with a single event of spermatozoa at the end of spermatogenesis, differently from the testis of amphibians, which present continuous development of spatial germinative cells resulting in sperm release waves during mating (Russell et al. 1990 apud Gribbins et al. 2006, Kumar 1995 apud Gribbins et al. 2006). In ocean turtles, Hamann et al. (2003) reported that the spermatogenic process occurred approximately in nine months, with emergence of primary and secondary spermatocytes for six months, and then of spermatids that remained for two to three months before the maximum spermatogenesis peak. After that, the spermatozoa followed through the ductuli efferentes to the epididymides (Wyneken 2001), where they were matured and remained active for approximately 30 days (Miller 1997 apud Gomes et al. 2006). In Pelodiscus sinensis (Zhang et al. 2008) and T. scripta (Gribbins et al. 2006), spermatogenesis follows this post-nuptial pattern, that is, it begins in May with the proliferation of spermatogonia. In June, the meiotic phase begins, and continues throughout the summer and early autumn, ending with spermiation in November. This pattern of spermatogenesis development in turtles, as well as the use of the epididymides to store spermatozoa for long periods of time (Holmes \& Gist 2004) so that they can be used in mating throughout the year (Gist et al. 2000), could explain the fact that, in some specimens, spermatozoa were observed only in the epididymides while the seminiferous tubules were empty.

After production inside the testes, spermatozoa are carried to the epididymides through the ductuli efferentes as described in mammals (Hafez \& Hafez 2004) and other turtle species (Carvalho et al. 2010, Cabral et al. 2011a, Olukole et al. 2014). The anatomical description of the epididymides as convoluted tubules, elongated caudally, and attached to the mid-end caudal of each testis by the mesorchium, through which they attached to the dorsal wall of the body, was similar to those provided by other authors (Carvalho et al. 2010, Cabral et al. 2011a, Malvasio et al. 2012). Unlike domestic species (Dyce et al. 1997), in T. scripta elegans, it was not possible to differentiate anatomically between the head, body and tail of the epididymis, as in K. scorpioides (Carvalho et al. 2010) and P. castaneus (Olukole et al. 2014). Dark epididymides were also observed in T. scripta (Aschley 1969) and Crysemys picta (Holmes \& Gist 2004), contrasting with their whitish color in P. geoffroanus (Cabral et al. 2011a) and K. scorpioides (Carvalho et al. 2010) and beige in P. castaneus (Olukole et al. 2014). After maturation in the epididymides, the spermatozoa are transported to the base of the penis through the vas deferens that deposits them in the urethral groove, as described in other species of turtles (Carvalho et al. 2010, Cabral et al. 2011a, Malvasio et al. 2012). The absence of ampulla in the ductus deferens was similar to that verified in K. scorpioides (Carvalho et al. 2010) and P. geoffroanus (Cabral et al. 2011a).

The histological morphology of the epididymis head in T. scripta elegans, with presence of ductuli efferentes and epididymal duct interspersed with connective tissue was similar to that of other turtles (Cabral et al. 2011b, Viana et al. 2013, Olukole et al. 2014). The ductuli efferentes are responsible for the transport of spermatozoa from the testis to the epididymis, and present epithelium capable of reabsorbing more than $90 \%$ of the luminal fluid, increasing the concentration of spermatozoa entering the epididymis (Hansen et al. 2004). In T. scripta elegans, groups of three to 10 ductuli efferentes were observed, as in hamsters (3-10; Ford Junior et al. 2014), mammals (5-10; Acharya et al. 2015), and Pelusios castaneus (5-8; Olukole et al. 2014), whereas the observed simple columnar epithelium differed from the pseudostratified columnar epithelium with areas of ciliated and non-ciliated cells in P. geoffroanus (Cabral et al. 2011b); of the simple cuboidal epithelium in K. scorpioides (Viana et al. 2013), and of the pseudostratified columnar epithelium in Pelusios castaneus (Olukole et al. 2014). In contrast, presence of smooth muscle tissue and loose connective tissue surrounding the ductuli efferentes, irregular contour, and empty lumen were also observed in these species. In T. scripta elegans, the epididymal duct showed simple columnar epithelium, contrasting with the pseudostratified columnar epithelium in P. geoffroanus (Cabral et al. 2011b), with epithelium varying between pseudostratified columnar and simple cuboidal in K. scorpioides (Viana et al. 2013), and with the pseudostratified columnar epithelium in Pelusios castaneus (Olukole et al. 2014). Alike to these species, the epididymal duct in T. scripta elegans was surrounded by smooth muscle tissue and loose connective tissue, the epithelium was composed of principal and basal cells, and the lumen was filled with spermatozoa. The heterogeneous shape of the principal cells and the location of the basal cells agreed with the findings described by Cabral et al. (2011b) and with the description in Pelusios castaneus (Olukole et al. 2014). In the present study, spermatozoa were found in the epididymal duct of all specimens analyzed, corroborating other studies (Viana et al. 2013, Olukole et al. 2014). According to Gist et al. (2000), in species with seasonal reproduction, spermatozoa produced during the summer are stored in the epididymides and used in mating throughout the year.

When the tetrapod evolved from the aquatic environment to the terrestrial environment, a set of traits had to evolve to enable their habitation. Thus, reproduction success in this new environment was assured by the amniotic egg, which no longer used the aquatic environment for fertilization or development, and fertilization became internal (Kardong 2011). To this end, reptiles had to develop special copulatory organs (Storer et al. 2000): lizards and snakes developed a pair of structures present laterally to the cloaca - the hemi-penis, whereas turtles and crocodiles developed a single medial phallus cranioventral to the cloaca, which seems to be homologous to the mammalian penis (Carvalho et al. 2010), developing with similarity of the embryonic origin to the gene expression pattern (Larkins \& 
Cohn 2015). Nevertheless, these authors pointed out that, unlike mammals, which present a closed urethral groove inside the penis, in reptiles and birds this groove remains open to facilitate the directional flow of spermatozoa along the penis, and it is termed spermatic sulcus.

Similarly to other turtle species (Wyneken 2001, Carvalho et al. 2010, Cabral et al. 2011a), the penis in T. scripta elegans was a single retractile organ with copulatory function only, positioned longitudinally to the ventral wall of the cloaca. As in other turtle species, it also comprised root, body and glans (Carvalho et al. 2010, Cabral et al. 2011a), and differed from the latter in mammals because they did not present penile spongy body and urethra, nor allowed the passage of urine (Hafez \& Hafez 2004). The presence of structures responsible for eversion and retraction of the penis at its root and of corpora cavernosa separated by the spermatic sulcus was similar to the descriptions in K. scorpioides (Carvalho et al. 2010) and P.geoffroanus (Cabral et al. 2011a); however, unlike these, the penis of T. scripta elegans did not show dark and tapered glans. Goulart (2004) emphasized that the corpora cavernosa fill with blood during erection, causing distension of the penis, whereas the sulcus forms a groove through which spermatozoa is transported. Presence of collagen fibers on the wall of erectile penis, arranged in layers alternating with fibers arranged parallel or perpendicular to the longitudinal axis of the organ, also occurs in mammals and T. scripta, but differs from mammals because they have only one layer of fibers in each orientation (Kelly 2004); another difference is that, although the aspect that leads to the development of the penis is homologous in turtles and mammals (Raff 1996 apud Kelly 2004), the tissues that originate it are not homogeneous (Perriton et al. 2002).

\section{CONCLUSIONS}

Biometry and morphology of the reproductive tract of males of Trachemys scripta elegans resemble, in some aspects, those of other turtle species and mammalian species, suggesting conserved morphology among turtles and homology to mammals.

The main differences in reproductive biology occur in spermatogenesis, with development of a single germ cell population and a single event of spermatozoa at the end of it; in the long-time storage of spermatozoa in the epididymis to use in mating throughout the year; in the penis, with open urethral groove, absence of spongy body and penile urethra, and essentially copulatory function.

Histological similarity with the reproductive organs of other amniotes, including humans, can give rise to scientific and comparative studies and, together with the differences in reproductive biology, contribute to the establishment of strategies of conservation, preservation and control in reptiles.

Conflict of interest statement.- The authors have no competing interests.

\section{REFERENCES}

Acharya N., Majumdar S. \& Ramayya R. 2015. Handbook of Male Infertility and Andrology. The Health Sciences Publisher, New Delhi, p.3.

Aversi-Ferreira T.A., Souza Lima e Silva M., Pereira de Paula J., Gouveia e Silva L.F. \& Penha Silva N 2005. Anatomia comparativa dos nervos do braço de Cebus apella: descrição do músculo dorsoepitroclear. Acta Scient., Biol. Sci. 27(3):291-296. http://dx.doi.org/10.4025/actascibiolsci.v27i3.1338.
Bager A. 2003. Aspectos da biologia e ecologia da tartaruga tigre d'água, Trachemys dorbignyi (Testudines, Emydidae) no extremo sul do Rio Grande do Sul, Brasil. Doctor of Science in Biological Sciences, Universidade Federal do Rio Grande do Sul, Porto Alegre, RS. 100p.

Bager A., Freitas T.R.O. \& Krause L. 2010. Morphological characterization of adults of Orbigny's slider Trachemys dorbignyi (Duméril and Bibron, 1835) (Testudines, Emydidae) in southern Brazil. Trop. Zool. 23:181-194.

Batistella A.M. 2008. Biologia de Trachemys adiutrix (Vanzolini, 1995) (Testudines, Emydidae) no litoral do Nordeste, Brasil. Doctor of Science in Biological Sciences, Universidade Federal d Amazonas, Manaus, AM. 82p.

Buhlmann, K. A., Hudson, R. R. \& Anders G. J. 2002. A global action plan for conservation of tortoises and freshwater turtles. Strategy and funding prospectus 2002-2007. Conservation International and Chelonian Research Foundation, Turtle Conservation Found, Washington, DC, 30p.

Bujes C.S., Molina F.N. \& Verrastro L. 2011. Population characteristics of Trachemys dorbigni (Testudines, Emydidae) from delta do Jacuí state park, Rio Grande do Sul, Southern Brazil. S. Am. J. Herpetol. 6(1):27-34. http:// dx.doi.org/10.2994/057.006.0104.

Cabral S.R.P., Santos L.R.S., Franco-Belussi L., Zieri R., Zago C.E.S. \& Oliveira C. 2011a. Anatomy of the male reproductive system of Phrynops geoffroanus (Testudines, Chelidae). Acta Scient., Biol. Sci. 33(4):487-492.

Cabral S.R.P., Zieri R., Franco-Belussi L., Santos L.R.S., Zago C.E.S., Taboga S.R. \& Oliveira C. 2011b. Morphological changes of the epididymis and description of the excurrent ducts of Phrynops geoffroanus (Testudines, Chelidae) during the reproductive cycle. Anat. Rec. 294(1):145-155. http:// dx.doi.org/10.1002/ar.21302. PMid:21157925.

Carvalho R.C., Oliveira S.C.R., Bombonato P.P., Oliveira A.S. \& Sousa A.L. 2010 Morfologia dos órgãos genitais masculinos do Jurará Kinosternon scorpioides (Chelonia, Kinosternidae). Pesq. Vet. Bras. 30(4):289-294. http://dx.doi. org/10.1590/S0100-736X2010000400001.

Close L.M. \& Seigel R.A. 1997. Differences in body size among populations of redeared sliders (Trachemys scripta elegans) subjected to different levels of harvesting. Chelonian Conserv. Biol. 2:563-566.

Cooke S.J., Sack L., Franklin C.E., Farrell A.P., Beardall J., Wikelski M. \& Chown S.L. 2013. What is conservation physiology? Perspectives on an increasingly integrated and essential science. Conserv. Physiol. 1(1):1-23. http://dx.doi. org/10.1093/conphys/cot001. PMid:27293585.

Courot M., Hochereau-De-Reviers M.T. \& Ortavant R. 1970. Spermatogenesis, p.339-431. In: Johnson A.D., Gomes W.R. \& Vandemark N.L. (Eds), The Testis. Vol.1. Academic Press, New York.

Daza J.M. \& Paez V.P. 2007. Morphometric variation and its effect on reproductive potential in female Colombian Slider Turtles (Trachemys callirostris callirostris). Herpetologica 63(2):125-134. http://dx.doi. org/10.1655/0018-0831(2007)63[125:MVAIE0]2.0.CO;2.

Duarte D.L.V., Monteiro D.S., Jardim R.D., Soares J.C.M. \& Varela-Junior A.S. 2011 Determinação sexual e maturação gonadal de fêmeas de tartaruga-verde (Chelonia mydas) e tartaruga-cabeçuda (Caretta caretta) no extremo sul do Brasil. Acta Biol. Parana. 30(3/4):87-103. http://dx.doi.org/10.5380/ abpr.v40i(1-4).25130.

Dyce K.M., Sack W.O. \& Wensing C.J.G. 1997. Tratado de Anatomia Veterinária. 2nd ed. Guanabara Koogan, Rio de Janeiro, 663p.

Fonseca F.O. 2001. Olhares sobre o lago Paranoá. Secretaria de Meio Ambiente e Recursos Hídricos, Brasília, DF. 425p.

Ford Junior J., Carnes K. \& Hess R.A. 2014. Ductuli efferentes of the male Golden Syrian hamster reproductive tract. Andrology 2(4):510-520. http://dx.doi.org/10.1111/j.2047-2927.2014.00194.x. PMid:24677666.

Gist D.H., Turner T.W. \& Congdon J.D. 2000. Chemical and thermal effects on the viability and motility of spermatozoa from the turtle epididymis. J. Reprod. Fertil. 119(2):271-277. http://dx.doi.org/10.1530/reprod/119.2.271. PMid:10864839.

Gomes M.G.T., Santos M.R.D. \& Henry M. 2006. Tartarugas marinhas de ocorrência no Brasil: hábitos e aspectos da biologia da reprodução. Revta Bras. Reprod. Anim. 30(1/2):19-27.

Goulart C.E.S. 2004. Herpetologia, Herpetocultura e Medicina de Répteis L.F. Livros de Veterinária, Rio de Janeiro, p.37-56. 
Gradela A., Santiago T.O.C., Pires I.C., Silva A.C.S., Souza L.C., Faria M.D., Pereira Neto J. \& Milanelo L. 2017. Sexual dimorphism in red-eared sliders (Trachemys scripta elegans) from the Wild Animal Triage Center of the Tiete Ecological Park, São Paulo, Brazil. Acta Scient. Vet. 45(1):1468. http:// dx.doi.org/10.22456/1679-9216.80442.

Gribbins K.M. 2011. Reptilian spermatogenesis: a histological and ultrastructural perspective. Spermatogenesis 1(3):250-269. http://dx.doi.org/10.4161/ spmg.1.3.18092. PMid:22319673.

Gribbins K.M., Gist D.H. \& Congdon J.D. 2003. Cytological evaluation of spermatogenesis and organization of the germinal epithelium in the male slider turtle, Trachemys scripta. J. Morphol. 255(3):337-346. http://dx.doi. org/10.1002/jmor.10069. PMid:12520551.

Gribbins K.M., Elsey R.M. \& Gist D.H. 2006. Cytological evaluation of the germ cell development strategy within the testis of the American alligator, Alligator mississippiensis. Acta Zool. 87(1):59-69. http://dx.doi.org/10.1111/j.14636395.2006.00220.x.

Hafez E.S.E. \& Hafez B. 2004. Reprodução Animal. 7th ed. Manole, São Paulo, 513p.

Hamann M., Limpus C.J. \& Owens D.W. 2003. Reproductive cycles of males and females, p.135-161. In: Lutz P.L., Musick J.A. \& Wyneken J. (Eds), The Biology of Sea Turtles II. CRC Press Book, Boca Ratón, Florida.

Hansen L.A., Dacheux F., Man S.Y., Clulow J. \& Jones R.C. 2004. Fluid reabsorption by the ductuli efferentes testis of the rat is dependent on both sodium and chlorine. Biol. Reprod. 71(2):410-416. http://dx.doi.org/10.1095/ biolreprod.104.027490. PMid:15056565.

Holmes H.J. \& Gist D.H. 2004. Excurrent duct system of the male turtle Crysemys picta. J. Morphol. 261(3):312-322. http://dx.doi.org/10.1002/ jmor.10251. PMid:15281059.

Hulme P.E. 2006. Beyond control: wider implications for the management of biological invasions. J. Appl. Ecol. 43(5):835-847. http://dx.doi. org/10.1111/j.1365-2664.2006.01227.x.

Junqueira L.C. \& Carneiro J. 2011. Aparelho reprodutor masculino, p.323-334. In: Junqueira L.C. \& Carneiro J. (Eds), Histologia básica. 11th ed. Guanabara Koogan, Rio de Janeiro.

Kardong K. 2011. Vertebrates: comparative anatomy, function, and evolution 6th ed. McGraw-Hill, Boston. 794p.

Keller R.P., Frang K. \& Lodge D.M. 2008. Preventing the spread of invasive species: economic benefits of intervention guided by ecological predictions. Conserv. Biol. 22(1):80-88. http://dx.doi.org/10.1111/j.1523-1739.2007.00811.x. PMid:18254855.

Kelly D.A. 2004. Turtles and mammals penis designs are anatomically convergent. Biol. Lett. 271:93-95.

Kondak H.C. 2012. Análise da proporção sexual e do desenvolvimento gonadal de tartaruga-verde, Chelonia mydas (Linnaeus, 1758), no litoral norte e médio do Rio Grande do Sul. Master Thesis in Fauna Diversity and Conservation, Universidade Federal do Rio Grande do Sul, Porto Alegre, RS. 41p.

Larkins C.E. \& Cohn M.J. 2015. Phallus development in the turtle Trachemys scripta. Sex Develop. 9(1):34-42. http://dx.doi.org/10.1159/000363631. PMid:24969757.

Lutz P.L., Musick J.A. \& Wyneken J. 2003. The Biology of Sea Turtle II. CRC Press, Boca Raton, Florida, p.135-161.

Malvasio A., Gomes N. \& Farias E.C. 1999. Identificação sexual através do estudo anatômico do sistema urogenital em recém-eclodidos e jovens de Trachemys dorbignyi (Duméril and Bibron) (Reptilia, Testudines, Emydidae). Revta Bras. Zool. 16(1):91-102. http://dx.doi.org/10.1590/ S0101-81751999000100004

Malvasio A., Souza A.M., Reis E.S. \& Salera Junior G. 2005. Relações entre as medidas das gônadas de machos e fêmeas em recém eclodidos de Podocnemis unifilis (Troschel, 1848). Public. Avulsas Inst. Pau Brasil 8-9:91-94.

Malvasio A., Nascimento-Rocha J.M., Santos H.D., Ataídes A.G. \& Portelinha T.C.G. 2012. Morfometria e histologia das gônadas de machos e fêmeas recém eclodidos de Podocnemis expansa e Podocnemis unifilis (Testudines, Podocnemididae). Acta Scient., Biol. Sci. 34(1):105-112. http://dx.doi. org/10.4025/actascibiolsci.v34i1.7257.
Moura I.O., Gomes-Klein V.L., Felfili J.M. \& Ferreira H.D. 2007. Fitossociologia da comunidade lenhosa de uma área de cerrado rupestre no Parque Estadual dos Pireneus, Pirenópolis, Goiás. Rev. Biol. Neotrop. 4:83-100.

Olukole S.G., Oyeyemi M.O. \& Oke B.O. 2014. Biometrical and histometrical observations on the testis and epididymis of the African sideneck turtle (Pelusios castaneus). Eur. J. Anat. 18(2):102-108.

Pérez E., Ruiz A., Espinosa G. \& Lee I. 2010. Histología gonadal y criterios fenotípicos de maduración en las tortugas marinas Chelonia mydas y Eretmochelys imbricata (Testudines: Chelonidae) de Cuba. Int. J. Trop. Biol. 58(1):287-298. PMid:20411723.

Perriton C.L., Powles N., Chiang C., Maconochie M.K. \& Cohn M.J. 2002. Sonic hedgehog signalling from the urethral epithelium controls external genital development. Develop. Biol. 247(1):26-46. http://dx.doi.org/10.1006/ dbio.2002.0668. PMid:12074550.

Primack R.B. \& Rodrigues E. 2001. Biologia da Conservação. Monograf, Londrina. 328p.

Readel A.M., Warner J.K., Holberton R.L. \& Phillips C.A. 2008. Maturational changes in male slider turtles (Trachemys scripta) from Illinois. Herpetol. Conserv. Biol. 3(2):170-175.

Rosa L. 2009. Biologia reprodutiva da tartaruga marinha Chelonia mydas no litroral paranaense. Master Thesis in Biological Sciences, Universidade Federal do Paraná, Pontal do Paraná, PR. 30p.

Schluter D. 2000. The Ecology of Adaptive Radiation. Oxford University Press, Oxford. 288p.

Silveira M.L., Hartmann M.T. \& Bager A. 2012. Biometria, razão sexual e dimorfismo sexual de Trachemys dorbigni (Duméril and Bibron, 1835) (Testudines, Emydidae) em um açude no município de São Gabriel, Rio Grande do Sul, Brasil. Biotemas 25(3):187-193. <http://dx.doi. org/10.5007/2175-7925.2012v25n3p187>

Sousa A.L., Campos-Junior P.H., Costa G.M. \& França L.R. 2014. Spermatogenic cycle length and sperm production in the freshwater turtle Kinosternon scorpioides. Biol. Reprod. 90(2):1-10. <http://dx.doi.org/10.1095/ biolreprod.113.112391><PMid:24403547>

Storer T.I., Usinger R.L., Stebbins R.C. \& Nybakken J.W. 2000. Zoologia Geral. 6th ed. Companhia Editora Nacional, São Paulo, p.642-654.

Thomas R.B. 2002. Conditional mating strategy in a long-lived vertebrate: ontogenetic shifts in the mating tactics of male slider turtles (Trachemys scripta). Copeia 2002(2):456-461. <http://dx.doi.org/10.1643/00458511(2002)002[0456:CMSIAL]2.0.CO;2>

Valenzuela N., Botero R. \& Martínez E. 1997. Field study of sex determination in Podocnemis expansa from Colombian Amazonia. Herpetologica 53(3):390-395.

Viana D.C., Rui L.A., Miglino M.A., Araujo L.P.F., Oliveira A.S. \& Sousa A.L. 2013. Morphological study of epididymides in the scorpion mud turtle in natural habitat (Kinosternon scorpioides Linnaeus, 1976). Biotemas 26(2):153-162. <http://dx.doi.org/10.5007/2175-7925.2013v26n2p153>

Vieira C.S. \& Costa E.M.E. 2006. Análise da estrutura populacional de Trachemys scripta elegans (Chelonia) no Parque Ecológico Olhos D’água, Brasília, DF. Universitas. Ciênc. Saúde 4(1/2):1-8.

Vogt R.C. \& Bull J. 1982. Temperature controlled sex-determination in turtles: ecological and behavioral aspects. Herpetologica 38(1):156-164.

Wyneken J. 2001. The Anatomy of Sea Turtles. NOAA, Miami, Florida, 180p.

Wyneken J. 2004. La Anatomía de las tortugas marinas. NOAA Technical Memorandum NMFS-SEFSC-470, U.S. Department of Commerce, Miami, Florida. 172p.

Zhang L., Han X.-K., Qi Y.-Y., Liu Y. \& Chen Q.-S. 2008. Seasonal effects on apoptosis and proliferation of germ cells in the testes of the Chinese softshelled turtle, Pelodiscus sinensis. Theriogenology 69(9):1148-1158. <http:// dx.doi.org/10.1016/j.theriogenology.2008.01.028> <PMid:18377973> 